Paideusis

\title{
John Dewey and the High Tide of American Liberalism (Alan Ryan)
}

\section{Douglas J. Simpson}

Volume 10, Number 2, 1997

URI: https://id.erudit.org/iderudit/1073183ar

DOI: https://doi.org/10.7202/1073183ar

See table of contents

Publisher(s)

Canadian Philosophy of Education Society

\section{ISSN}

0838-4517 (print)

1916-0348 (digital)

Explore this journal

\section{Cite this review}

Simpson, D. (1997). Review of [John Dewey and the High Tide of American Liberalism (Alan Ryan)]. Paideusis, 10(2), 47-48.

https://doi.org/10.7202/1073183ar 


\section{Book Reviews}

\section{Alan Ryan. John Dewey and the High Tide of American Liberalism. New York: W.W. Norton \& Company, 1995.}

Occasionally, we encounter works written about significant people that demonstrate the complexities of a person's background, milieu, life, personality, thought, and development while avoiding demonizing or deifying the individual and eschewing an aggressive authorial agenda that reaches beyond understanding the person being studied. Even more rare is such a study of John Dewey, in part because of the voluminous Dewey canon, in part because of the evolutionary stages of his thought, and in part because many secondary sources offer problematic and superficial interpretations of his ideas. Ryan, however, has given us a volume that admirably meets these interests and avoids these pitfalls. He has read widely and wisely, thought contextually and reflectively, and written clearly and interestingly. Serious students of Dewey will welcome this book even if they differ on some of the specific interpretations offered. But I am getting ahead of myself. Beyond that which has already been suggested, what is there about Ryan's book that makes it valuable?

Two factors set the context for understanding Ryan's book as a whole and appreciating its overall value. First, the fact that the book views Dewey in the context of the Western world, rather than in a more narrow American setting, is illuminating. Examining him from this perspective, as Ryan notes, makes an important difference to what "seemed original and what seemed derivative" in Dewey (p. 12). Seeing Dewey in this "transatlantic light" is refreshing if not entirely new. Second, Ryan's rather successful effort to avoid reading into Dewey's writings current philosophical, political, religious, economic, and educational ideologies is likewise stimulating. Understanding what Dewey said and meant in his age appears more important to Ryan than attempting to argue that Dewey did or did not adequately foresee and support present-day normative programs or agendas. The evenhandedness with which Ryan treats a wide array of topics is also commendable, including his exceptional handling of Dewey's educational thought.

Another reason for recommending Ryan's book is the invigorating discussions of the development of Dewey both as a person (particularly pp. 1-83) and a thinker (pp. 84-369), resulting in the former being informed by the treatment of the latter. As Ryan follows Dewey from Vermont to Pennsylvania to Maryland to Michigan to Illinois to New York, there is a growing impression that the reader is emerging with a clearer and deeper understanding of Dewey the man as well as a greater insight into Dewey the philosopher. We are led toward believing, as only one example, that Dewey may have never sufficiently understood nor overcome his strong negative feelings toward his mother, Lucina. Thus, we gain insight on how these feelings may have influenced the development of his religious beliefs. So, Dewey the person emerges from the pages of John Dewey even when the discussion is focused on other people and themes.

We also find in Ryan's book provocative, if mainstream, discussions of Dewey's views on a number of concepts crucial during his time and pertinent to his philosophy (for example, liberalism, democracy, religion, morality, education, Marxism, art, politics, science, capitalism, war, progressive education, 
philosophy, pragmatism, communitarianism, experimentalism, and individualism). Insight into individuals who influenced, engaged, and/or annoyed Dewey, such as Alice Chipman Dewey, George Herbert Mead, Nicholas Murray Butler, H. A. Torrey, George Sylvester Morris, Sidney Hook, G. W. F. Hegel, Albert Barnes, Bertrand Russell, William James, Reinhold Niebuhr, G. Stanley Hall, Leon Trotsky, Thomas Hill Green, Charles Sanders Peirce, Walter Lippmann, Immanuel Kant, William H. Kilpatrick, John Stuart Mill, Robert Hutchins, Jane Addams, and Randolph Bourne are explored in some detail. The meaning and significance of several volumes-How We Think, Individualism Old and New, Experience and Nature, Quest for Certainty, Freedom and Culture, Human Nature and Conduct, Reconstruction in Philosophy, Democracy and Education, Liberalism and Social Action, Art as Experience, and Public and Its Problems - are also pursued by Ryan. Throughout his discussions of these themes, people, and works, Ryan weaves a tapestry that makes Dewey look more human, finite, and fallible; less original, tough-minded, and awesome; yet consequential, visionary, and reflective. He emerges as a person, a human being, but still one of great intellectual vitality, social activism, and educational perception. Within this frame of reference, Ryan concludes on "a note of enthusiasm for Dewey's work and almost unalloyed admiration for its author" (p. 34).

Matters that may detract from Ryan's efforts include the inaccurate description of USA's best educated students (p. 26), the overuse of the term “obsession" when discussing Dewey's inclinations (see, for example, pp. 173, 277), the misrepresentation of the extent to which Dewey discussed high schools (p. 348), the conflation of Dewey's notions of noneducative and miseducative into a generic diseducative concept (p. 144), and the overstatement that it is unclear what a "Deweyan school" is like (pp. 147-148). We remain pleased, nevertheless, that Ryan avoided two often repeated misinterpretations of Dewey: the myth that Dewey was child-centered (p. 136) and the rumour that Dewey thought play was fundamentally detached from educative activities (pp. 139-140).

Ryan closes his book with the statement that Dewey will "remain for the foreseeable future a rich source of intellectual nourishment for anyone not absolutely locked within the anxieties of his or her own heart and not absolutely despondent about the prospects of the modern world" (p. 369). So, too, we conclude that Ryan's work will "remain for the foreseeable future a rich source of intellectual nourishment for anyone" interested in the life, intellectual history, and philosophy of John Dewey. Indeed, it is difficult to envision-even if one is not imaginatively challenged - a more thorough, reflective, invigorating, clear, yet concise treatment on the topics addressed than John Dewey and the High Tide of American Liberalism.

Reviewed by Douglas J. Simpson, Texas Christian University 